\title{
Consumption of picoplankton by the bivalve larvae of Japanese pearl oyster Pinctada fucata martensii
}

\author{
Yuji Tomaru $^{1, *}$, Zen'ichiro Kawabata ${ }^{2}$, Shin-ichi Nakano ${ }^{3}$ \\ ${ }^{1}$ Department of Environmental Conservation Sciences, The United Graduate School of Agricultural Sciences, Ehime \\ University, Tarumi 3-5-7, Matsuyama 790-8566, Ehime, Japan \\ ${ }^{2}$ Center for Ecological Research, Kyoto University, Otsuka 509-3, Kamitanakami-Hirano-cho, Otsu 520-2113, Shiga, Japan \\ ${ }^{3}$ Department of Environmental Conservation, Faculty of Agriculture, Ehime University, Tarumi 3-5-7, Matsuyama 790-8566, \\ Ehime, Japan
}

\begin{abstract}
We examined grazing on bacteria and algal picoplankton (APP) by the larvae of Pinctada fucata martensii, using fluorescently labeled bacteria (FLB) and algae (FLA). Ingestion of both FLB and FLA by the larvae indicated that bacteria and APP serve as food sources for the larvae. With natural assemblages of bacteria and APP, the clearance rates of bacteria by the larvae (70 to $200 \mu \mathrm{m}$ ) ranged between 0.08 and $0.12 \mu l$ larva ${ }^{-1} \mathrm{~h}^{-1}$, and those of APP between 0.12 and $1.5 \mu l$ larva ${ }^{-1} \mathrm{~h}^{-1}$ Grazing pressure on natural populations of bacteria and APP by the larvae was estimated as $<0.01 \% \mathrm{~d}^{-1}$ in Uchiumi Bay, suggesting that these larvae play a minor role in the consumption of picoplankton.
\end{abstract}

KEY WORDS: Pearl oyster larvae $\cdot$ Clearance rate $\cdot$ Picoplankton

\section{INTRODUCTION}

Previous studies have demonstrated that bivalve larvae graze on particles of 2 to $10 \mu \mathrm{m}$ as their primary diet (Riisgard et al. 1980, Fritz et al. 1984) but recent studies have shown that some bivalve larvae ingest the much smaller bacteria or algal picoplankton (APP) (Douillet 1993a,b, Gallager et al. 1994). The $<2 \mu \mathrm{m}$ plankton account for a substantial part of the planktonic biomass in marine environments (Waterbury et al. 1986). The food linkages between $<2 \mu \mathrm{m}$ plankton and protists have been well studied (Fenchel 1982, Sherr et al. 1987, 1991, Rassoulzadegan et al. 1988, Rublee \& Gallegous 1989, James et al. 1996) and turnover rates of $<2 \mu \mathrm{m}$ plankton by protists have been estimated as 1 to $45 \% \mathrm{~d}^{-1}$ in some marine environments (Sherr et al. 1987, 1991, Rassoulzadegan et al. 1988, James et al. 1996). Although bivalve larvae may be one of the important picoplankton grazers, information about their feeding on $<2 \mu \mathrm{m}$ plankton is still limited, unlike that of flagellates and ciliates.

\footnotetext{
•E-mail: tomaruy@agr.ehime-u.ac.jp
}

In Uchiumi Bay of Ehime Prefecture, Japan, culture of the bivalve pearl oyster Pinctada fucata martensii is extensively practiced. During the oyster breeding season, in early summer, their larvae are temporarily very abundant in the culture areas (Seki 1960) and may thus play an important role in the cycling of matter in the bay.

The main diet of adult Pinctada fucata martensii is diatoms (Fukushima 1972) and particles of 2 to $5 \mu \mathrm{m}$ (Sawano 1950, Kuwatani 1965), and the cultured larvae graze phytoplankton (e.g. Pavlova lutheri, Chaetoceros gracilis, Isocrysis galbana) (Hayashi \& Seko $1986)$ as well as other bivalve larvae in the culture systems (Hirano \& Ohshima 1963). Since the larvae of the pearl oyster are also ciliated suspension feeders, they may ingest picoplankton such as bacteria. However, we do not have any information about picoplankton grazing by these larvae. In the present study, we examined consumption of picoplankton by oyster larvae using fluorescently labeled bacteria (FLB) and algae (FLA). These fluorescent particles are often used for measuring consumption of bacteria by protists (Sherr et al. 1987, 1991, Nakano et al. 1998a,b). 


\section{MATERIALS AND METHODS}

Preparation of the larvae. The seeding of bivalve pearl oyster Pinctada fucata martensii larvae was carried out at the Uchiumi Institute of Oceanic and Fishery Science on 6 May 1997, and at the Uwajima City Fisheries Seeding Production Center on 2 February, 3 March and 14 May 1998. Artificial seeding of the pearl oyster was conducted by the temperature stimuli method (Hayashi \& Seko 1986). P. fucata martensij adults and larvae were fed on Pavlova lutheri or Isocrysis garbana during the culture. The larvae thus treated were used for all experiments in the present study. The size of the larvae used in each experiment is shown in Table 1

Feeding of the larvae in natural seawater. We conducted experiments on 15 May, 26 May and 2 June 1997, to examine grazing on bacteria and phytoplankton by the larvae. An 800 I water sample was collected $1 \mathrm{~m}$ below the surface using a pump at the barge in front of the institute. It was filtered through a plankton net with $200 \mu \mathrm{m}$ mesh to remove larger particles and $200 \mathrm{l}$ of the filtered water was poured into each of 4 tanks. A certain number of larvae were inoculated into 2 of the tanks ( 0.5 to 1 ind. $\left.\mathrm{ml}^{-1}\right)$ which served as the experimental replicates, while the other 2 acted as the controls. The concentration of the larvae in Uchiumi Bay was 3.6 ind. $\mathrm{l}^{-1}$ at the maximum in the preliminary survey, thus larval density in this experiment was higher than that of the bay. The cultures were maintained at $25^{\circ} \mathrm{C}$ in the dark with $21 \mathrm{~min}^{-1}$ continuous air bubbling. We took subsamples from each tank at 0,6 , 12 and $24 \mathrm{~h}$ after inoculation to follow temporal changes in concentration of chlorophyll a (chl a), bacteria and phytoplankton cell densities

Table 1. Larval sizes and food particles used in feeding experiments. Food particles were collected from Uchiumi Bay (UC) and Uwajuma Bay (UW). Mean \pm standard deviation $(n=20)$ is given

\begin{tabular}{|c|c|c|}
\hline Larval size (ftm) & Food particle & Sampling day \\
\hline $45-80$ & UC & 15 May 1997 \\
\hline $80-100$ & UC & 26 May 1997 \\
\hline $100-200$ & UC & 2 June 1997 \\
\hline 1. d old (ca 70$)$ & FLB & \\
\hline 1 d old (ca 70) & FLA & \\
\hline $76 \pm 5$ & $U W+F L B$ & 13 May 1998 \\
\hline $95=8$ & $U W+F \perp B$ & 13 May 1998 \\
\hline $202 \pm 31$ & $U W+F L B$ & 27 May 1998 \\
\hline $76 \pm 5$ & UW + FLA & 13 May 1998 \\
\hline $95 \pm 8$ & $U W+F L A$ & 13 May 1998 \\
\hline $202 \pm 31$ & $\mathrm{UW}+\mathrm{FLA}$ & 27 May 1998 \\
\hline
\end{tabular}

Feeding on FLB or FLA. FLB and FLA, both of which have frequently been used to determine consumption of bacteria by protists (Sherr et al. 1987, 1991. Nakano et al. 1998a,b), were used in the present study to determine consumption of bacteria and algae by the bivalve larvae. We prepared FLB and FLA using the minicell-producing mutant strain of Escherichia coli and the cyanobacterium strain of Synechococcus $\mathrm{sp}$. The average diameters of the FLB and FLA were ca $0.8 \mu \mathrm{m}$ and 1 to $2 \mu \mathrm{m}$, respectively. These sizes are within a range of bacteria (Lee et al. 1995) and APP (Weisse 1993) in marine environments. A $100 \mathrm{ml}$ portion of $0.2 \mu \mathrm{m}$ filtered seawater was poured into 6 flasks. FLB were added to each flask at a final concentration of $1.8 \times 10^{5} \mathrm{FLB} \mathrm{ml}^{-1}$. Pinctada fucata martensii larvae were rinsed with $0.2 \mu \mathrm{m}$ filtered seawater and inoculated into 3 of the 6 flasks at a final concentration of 10 ind $\mathrm{ml}^{-1}$. The other 3 flasks served as the controls. The cultures were maintained at $25^{\circ} \mathrm{C}$. We took a $10 \mathrm{ml}$ subsample from each flask at $0,12,24$ and $48 \mathrm{~h}$ after inoculation with the larvae. The samples were fixed 1:1 with ice-cold buffered glutaraldehyde ( $2 \%$ final concentration) to minimize egestion of ingested FLB and FLA (Sanders et al. 1989). A $2 \mathrm{ml}$ portion of the fixed sample was filtered through a black $0.2 \mu \mathrm{m}$ Nuclepore filter. FLB and FLA cells were enumerated using an epifluorescence microscope under UV excitation. After enumeration, we took pictures of the FLB ingested by the larvae and accumulated in the digestive tract and stomach, using Kodak Ektachrome (ASA 400). We also carried out the same experiment using FLA at a final concentration of $2.0 \times 10^{5} \mathrm{FLA} \mathrm{ml}^{-1}$

Feeding rate on FLB or FLA in natural seawater. Seawater samples were collected from the surface layer in front of the center on 13 May and 27 May 1998. Concentrations of APP and bacteria in the natural water samples were determined prior to the experiment.

The larvae were washed with $0.2 \mu \mathrm{m}$ filtered seawater on the adequate size of the plankton net. The larvae thus treated were resuspended in the natural seawater, and $10 \mathrm{ml}$ portions of the seawater which contained actively swimming larvae at densities around 10 to 20 ind. $\mathrm{ml}^{-1}$ were poured into six $50 \mathrm{ml}$ test tubes. After $1 \mathrm{~h}$ of acclimation, FLB or FLA were added to these test tubes at a final concentration of $<10 \%$ of that of the same size particles in situ (McManus \& Okubo 1991). Separate test tubes wore set up for oach timo period. Zero, $5,10,20,30$ and 60 min after the addition of FLE or FLA, the larvae in each test tube were then fixed 1:1 with ice-cold buffered glutaraldehyde $12 \%$ final concentration) and kept in the dark at $4^{\circ} \mathrm{C}$ until microscopic analysis. The larvae were retained on black $5 \mathrm{~mm}$ Nuclepore filters. The larvae on the slides 
were well pressed with a cover glass for clear observation of FLB and FLA in the larval gut. The number of FLB or FLA in the larval digestive tract was counted under an epifluorescence microscope.

We calculated FLB or FLA uptake rates of the larvae ( $I_{\mathrm{f}}$ : FLB or FLA larva ${ }^{-1} \mathrm{~h}^{-1}$ ) from the linear portion of the curve of average number of fluorescently labeled particles larva ${ }^{-1}$ with time by using linear regression (Sherr et al. 1987). Specific clearance rate $\left(I_{c}: \mu l \operatorname{larva}^{-1}\right.$ $\mathrm{h}^{-1}$ ) of Pinctada fucata martensii larvae was calculated as follows

$$
I_{\mathrm{c}}=I_{\mathrm{f}} / N_{\mathrm{f}}
$$

where $N_{\mathrm{f}}$ is the density of surrogates (particles $\mu^{-1}$ ). Ingestion rate $\left(I_{i}\right.$ : bacteria or APP cells larva $\left.{ }^{-1} \mathrm{~h}^{-1}\right)$ of the larvae was calculated as

$$
I_{1}=I_{c} \times N_{\mathrm{p}}
$$

where $N_{\mathrm{p}}$ is the density of bacteria or APP (cells $\mu \mathrm{l}^{-1}$ ) Turnover rate $\left(I t: \% \mathrm{~d}^{-1}\right)$ is calculated as

$$
I_{\mathrm{t}}=100 \times\left(I_{\mathrm{i}} \times N_{\mathrm{L}} \times 24\right) / N_{\mathrm{p}}
$$

where $N_{\mathrm{L}}$ is the density of the larvae in the sea.

Abundance of organisms and analysis. The sizefractionated water samples which were prepared using $2.0 \mu \mathrm{m}$ pore size Nuclepore filters and a $20 \mu \mathrm{m}$ mesh size plankton net were filtered through $0.2 \mu \mathrm{m}$ pore size Nuclepore filters to retain seston. The chl a concentration was determined by the fluorometric method (Rami \& Porath 1980).

A $500 \mathrm{ml}$ water sample was fixed with acid Lugol's solution at a final concentration of $1 \%$, and concentrated to 1000 times by natural sedimentation. The phytoplankton thus concentrated was enumerated with a haemacytometer under a microscope. A $10 \mathrm{ml}$ portion of the sample for the bacterial count was fixed with neutral formalin at a final concentration of $1 \%$, and the bacterial cells were enumerated by the DAPI method (Porter \& Feig 1980). Ten ml subsamples for APP count were filtered through $0.2 \mu \mathrm{m}$ black prestained Nuclepore filters. APP cells were counted using an epifluorescence microscope under green excitation. Since some APP cells are not detectable using the epifluorescence microscope (Chisholm et al. 1988), our APP count might be underestimated.

Statistical analyses ( $t$-test) for the data were performed using STAT VIEW program ver. 2.0.2 (Abacus Concepts, Inc.).

\section{RESULTS}

The dominant phytoplankton species in May 1997 were Prorocentrum sp. (Dinophyceae) and Chaetoceros spp. (Bacillariophyceae). Chl $a$ in the 2 to $20 \mu \mathrm{m}$ fraction predominated in May 1997, followed by the $<2 \mu \mathrm{m}$ fraction. The $>20 \mu \mathrm{m}$ fraction was the minor component of the phytoplankton. Although concentrations of chl a in each size-fraction generally decreased with incubation time (Fig. 1), we could not find significant differences in chl a concentration between the control and experimental tanks.

The original bacterial concentration was ca 3 to $4 \times$

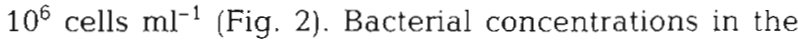
experiment using small and middle sized larvae did not change during the culture period (Fig. 2). In the experiment using large larvae, bacterial concentrations decreased from 0 to $12 \mathrm{~h}$ after incubation (Fig. 2); however, like the chl $a$, the bacterial concentrations were not different between the control and the experimental tanks.
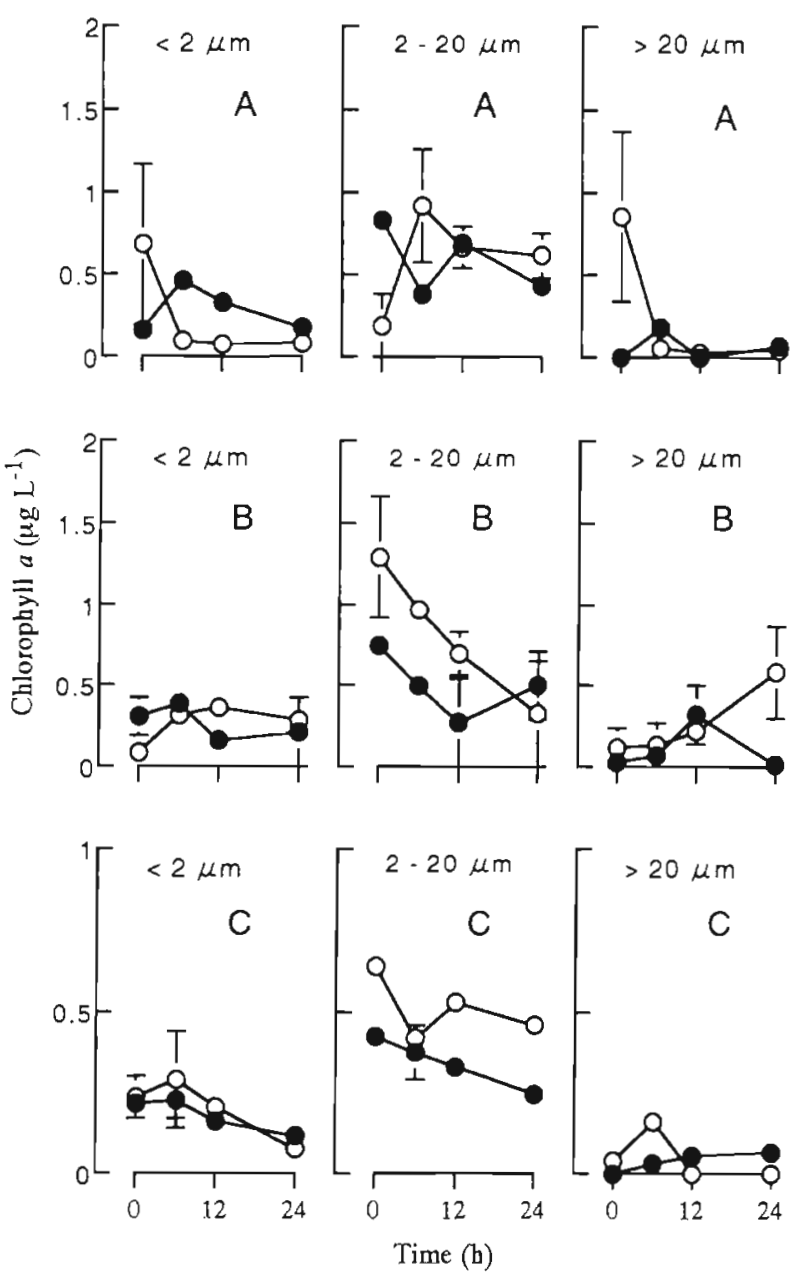

Fig. 1. Changes in size-fractionated chlorophyll a concentration in the control (O) and the experiment tanks (O) in the presence of (A) small (B) middle and (C) large larvae. Vertical bars which indicate differences in chlorophyll a concentration between duplicates are shown when they exceed the size of the symbol. Larval sizes are shown in Table 1 


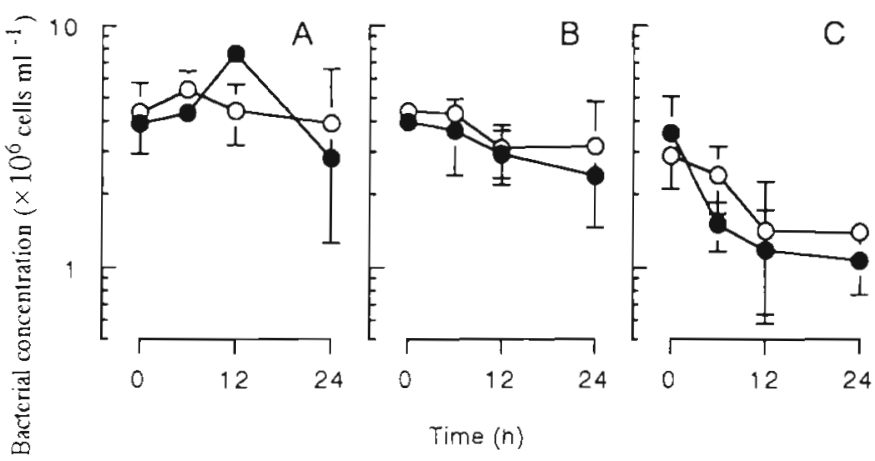

Fig. 2. Changes in bacterial concentration in the control (O) and the experiment tanks (-) in the presence of (A) small, (B) middle and (C) large larvae. Vertical bars which indicate maximum and minımum in cell concentration are shown when they exceed the size of the symbol. Larval sizes are shown in Table 1

We could detect both FLB (Fig. 3) and FLA ingested by Pinctada fucata martensii larvae. FLB were accumulated in the larval digestive tract or gut, and this is the evidence of bacterivory by the larvae (Fig 3). There were significant decreases in concentrations of FLB and FLA in the experimental flasks ( $p<0.05$ ), while concentrations of the fluorescent particles in the control varied little (Fig. 4)

The uptake of FLB by the larvae was linear relative to time within the first $30 \mathrm{~min}$ in all experiments and thereafter leveled off (Fig. 5). Higher clearance rates of bacteria were obtained for larger larvae $(0.08$ to $0.12 \mu \mathrm{l}$ larva $^{-1} \mathrm{~h}^{-1}$ ) (Table 2). FLA uptake by the larvae was saturated within $10 \mathrm{~min}$. The clearance rate on APP was almost the same as for the 76 to $96 \mu \mathrm{m}$ larvae ( 0.8 to $1.5 \mu$ larva $\left.^{-1} \mathrm{~h}^{-1}\right)$, whereas larger larvae showed lower rates $\left(0.12 \mu\right.$ larva $\left.^{-1} \mathrm{~h}^{-1}\right)$ (Table 2).

\section{DISCUSSION}

Previous studies have demonstrated that bivalve larvae show size-selective feeding on 2 to $10 \mu \mathrm{m}$ particles (Riisgard et al. 1980, Fritz et al. 1984, Baldwin 1995). Recent studies (Baldwin \& Newell 1991, Baldwin 1995) reported that bivalve larvae also ingest larger particles (>10 $\mathrm{\mu m}$ ). As bivalve larvae grow, they can feed on a wider size range of food particles (Baldwin 1995) such as large dinoflagellates (20 to $30 \mu \mathrm{m}$ ) (Baldwin \& Newell 1991, Baldwin 1995). The $>10 \mu \mathrm{m}$ food particles are important for oyster larvae (Baldwin \& Newell 1995). However, we could not find significant decreases due to grazing on 2 to $20 \mu \mathrm{m}$ phytoplankton by the larvae of Pinctada fucata martensii in the present study (Fig. 1), and there are 2 possible explanations for this. The first is negative effects on feeding of $P$. fucata martensii larvae by bubbling. Some authors have discussed the relationships between water stability and ingestion of organisms. The feeding rates of the cladoceran Daphnia longispina (Nagata \& Okamoto 1988) and a heterotrophic flagellate (Aulacomonas hyalina) (Mischke 1994) were decreased by water turbulence. The second is negligible grazing pressure on 2 to $20 \mu \mathrm{m}$

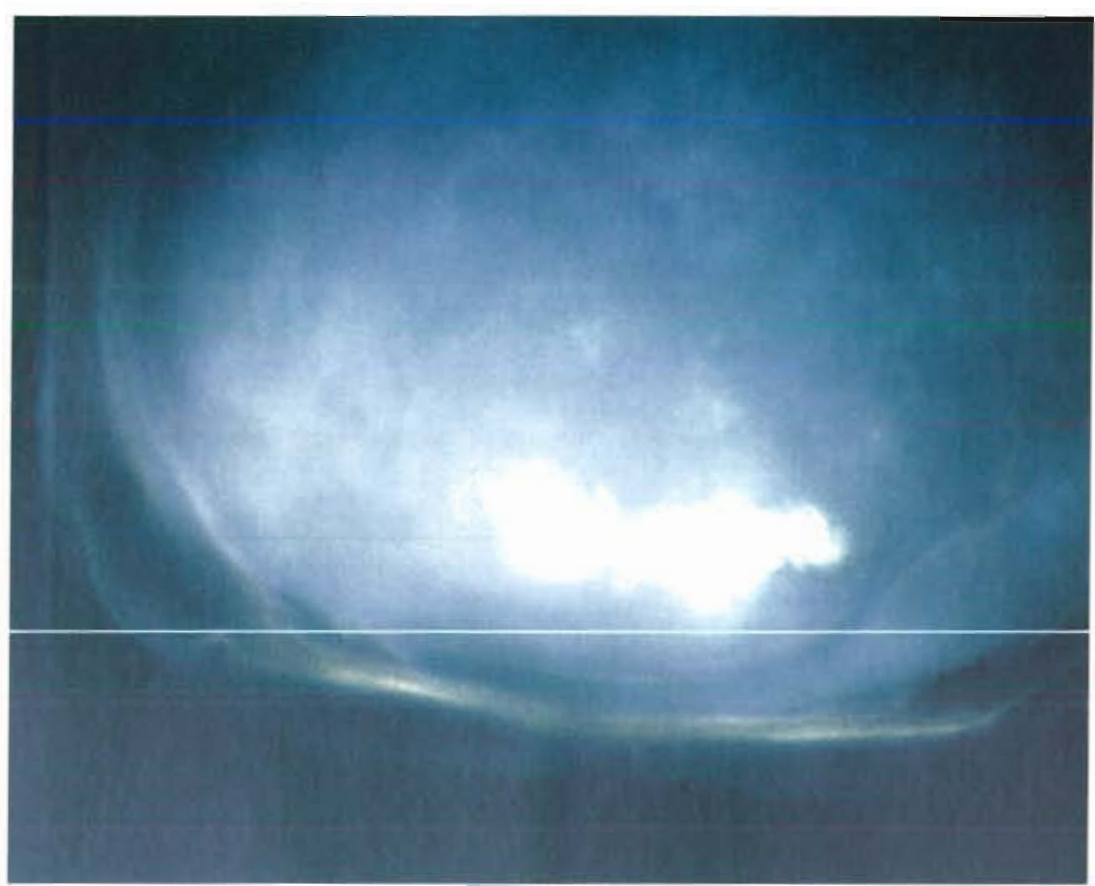

Fig. 3. FLB in the digestive tract of Pinctada fucata martensii larvae 

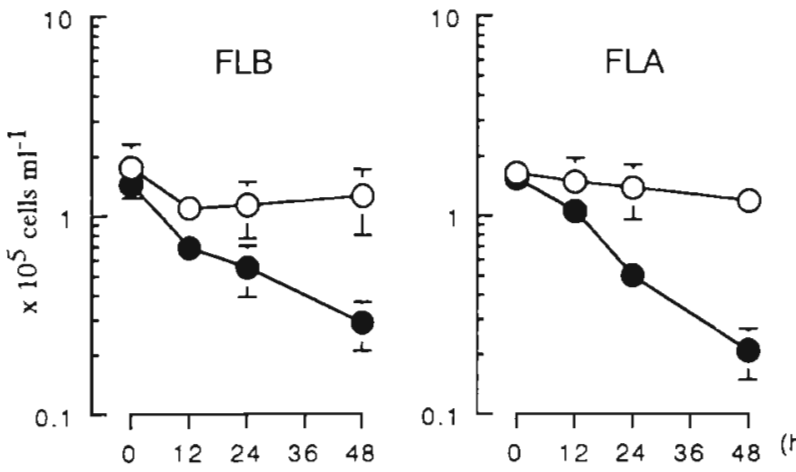

Fig. 4. Changes in FLB or FLA concentration in the control (O) and the experiment tanks (O). Vertical bars which indicate standard deviations in cell concentration are shown when they exceed the size of the symbol. Larval size was ca $70 \mu \mathrm{m}$ in both experiments

phytoplankton by the larvae relative to that of other herbivores such as ciliates and crustaceans. Edible food size of the larvae overlaps that of the herbivores (Baldwin \& Newell 1995), and grazing pressure on 2 to $20 \mu \mathrm{m}$ phytoplankton by the herbivores is considerably high (Kamiyama 1994, Kuipers \& Witte 1999).

Bivalve larvae could grow on bacterial food (Hidu \& Tubiash 1963, Douillet \& Langdon 1993). Recent studies have demonstrated that bivalve larvae were able to ingest bacteria (Prieur 1983, Baldwin \& Newell 1991, 1995, Douillet 1993a,b). In the present study, we also demonstrated evidence of grazing on bacteria and APP by the larvae of Pinctada fucata martensii (Figs. 3, 4 \& 5).

Significant decreases in the concentrations of $<2 \mu \mathrm{m}$ phytoplankton (APP) and bacteria due to grazing by the larvae were also not detectable (Figs. 1 \& 2). It is
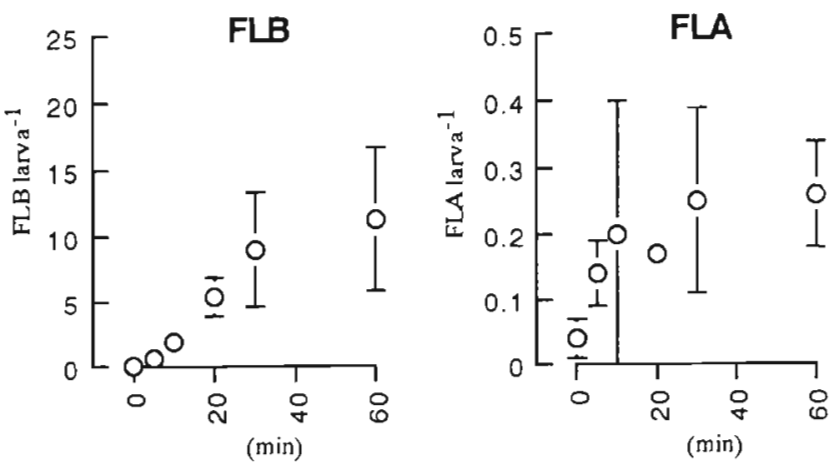

Fig. 5. Changes in the number of ingested FLB and FLA in Pinctada fucata martensii larvae. Vertical bars which indicate standard deviations in cell concentration are shown when they exceed the size of the symbol. Larval size was 76 and $95 \mu \mathrm{m}$ in FLB and FLA experiment, respectively

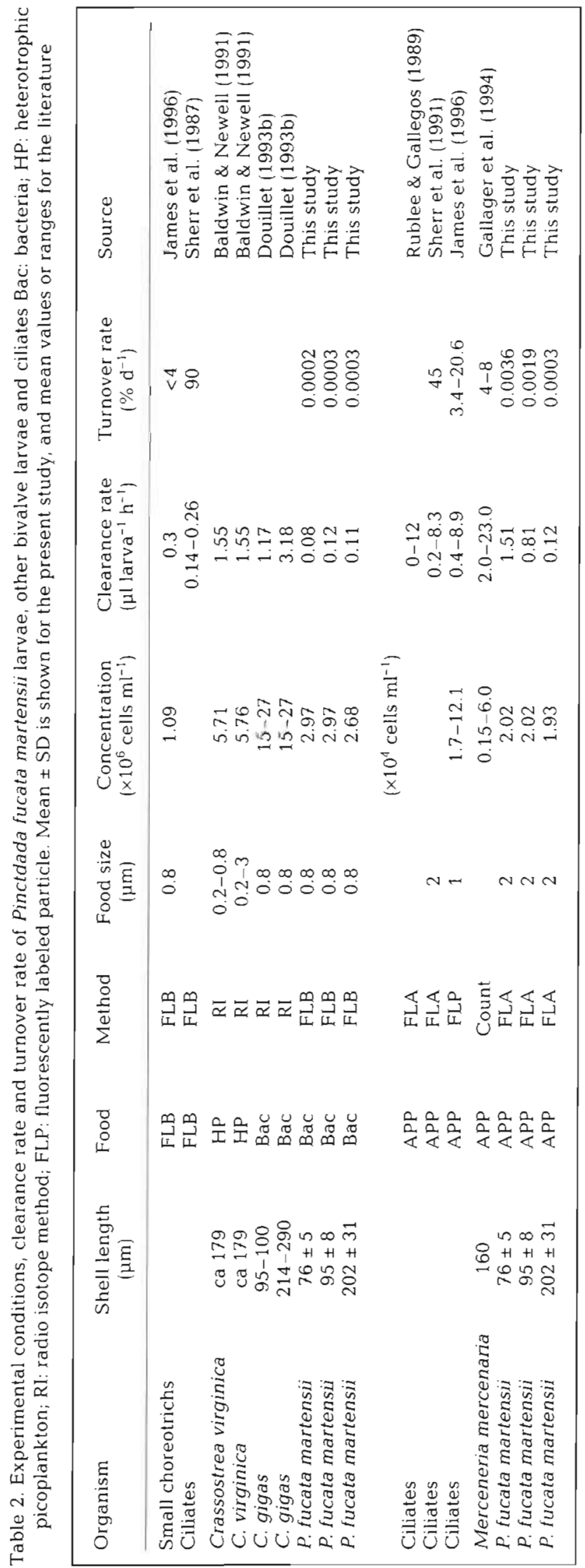


likely that the larvae excreted some nutritional substances for bacteria and APP (Stockner \& Antia 1986), and that the presence of the larvae had not only a negative (grazing) but also a positive (excretion) effect on these picoplankton. Thus, the bacterial and APP abundance in the experiments shown in Figs. 1 \& 2 were probably in equilibrium between loss by grazing and growth on excreted substances.

Previous studies have used radioisotopes (Baldwin \& Newell 1991, Douillet 1993b) and a flow cytometer (Baldwin \& Newell 1995) to measure the ingestion and clearance rates of picoplankton by bivalve larvae. However, the former method needs skillful technique and sometimes overestimates the actual clearance rates when the estimation was based on the Daro model (Baldwin \& Newell 1991). The latter method also has limitations due to the detection limit for smaller particles using a flow cytometer (Baldwin \& Newell 1995). It is difficult to detect particles with sizes $<1 \mu \mathrm{m}$ using a low-power laser flow cytometer (Olson et al. 1990, Baldwin \& Newell 1995). In addition to these technical problems, there is the possibility of growth of bacteria (Ferguson et al. 1984) and APP (Waterbury et al. 1986) in the presence of bivalve larvae during a long-term incubation ( 8 to $10 \mathrm{~h}$ ) (Baldwin \& Newell 1995), since the larvae excreted some food substances avalable for bacteria and APP Thus, consumption of bacteria and APP by bivalve larvae should be determined within a shorter time. Consumption of picoplankton by protists has been intensively examined in previous studies using FLB and FLA (Sherr et al. 1987, 1991, James et al. 1996, Nakano et al. $1998 \mathrm{a}, \mathrm{b})$. The method is simple and requires a short time (5 to $30 \mathrm{~min}$ ) (Sherr et al. 1987, 1991, Rublee \& Gallegos 1989, Nakano et al. 1998a,b).

Since we could not count the precise number of FLB ingested by the larvae from 30 to $60 \mathrm{~min}$ due to aggregation of the FLB in the gut, we recommend that the experimental time for determining the feeding rate of Pinctada fucata martensii larvae by the FLB method is within $30 \mathrm{~min}$ and FLA is $10 \mathrm{~min}$. For the experiment using FLA, uptake rate of the larvae was unfortunately low, and the deviation of the slope was large $(p>0.05)$ (Fig. 5). This might be due to low concentration of FLA $\left(1.25 \times 10^{3} \mathrm{FLA} \mathrm{ml}^{-1}\right)$. Thus some cautions should be taken into consideration for the method using FLA.

The present study is the first to use FLB and FLA to determine consumption of picoplankton by bivalve larvae. Although clearance rate of bivalve larvae on bacteria and APP may be easily estimated by using FLB and FLA, this method has some problems. The size of bacteria in a marine environment is usually 0.3 to $0.5 \mu \mathrm{m}$ (Lee et al. 1995), while the size of FLB used in the present study was larger (ca $0.8 \mu \mathrm{m}$ ) than that of average-sized natural bacteria. Thus it may be inap- propriate to use larger surrogates for determination of grazing rates of size-selective feeding animals. In addition, Landry et al. (1991) reported there was discrimination in bacterivory of the flagellate Paraphysomonus vestita between living and dead cells, while Mischke (1994) stated that bacterivory of these isolated flagellate strains was stimulated in the presence of fluorescently labeled prey. Thus, clearance rate on bacteria and APP by Pinctada fucata martensii larvae determined in the present study must be evaluated with some caution.

The clearance rate on picoplankton by Crassostrea virginica in a seawater sample ranged between 1.5 and $1.6 \mathrm{\mu l} \mathrm{larva}^{-1} \mathrm{~h}^{-1}$ (Baldwin \& Newell 1991), that of $C$. gigas larvae fed on high densities $(1.57$ to $2.65 \times$ $10^{7}$ cells $\mathrm{ml}^{-1}$ ) was between 1.17 and $3.18 \mu \mathrm{l}$ larva $^{-1} \mathrm{~h}^{-1}$ (Douillet 1993b), and that of Mercenaria mercenaria larvae fed on the cyanobacterium Synechococcus sp. was between 2 and $23 \mu$ larva $^{-1} \mathrm{~h}^{-1}$ (Gallager et al. 1994). The clearance rates on bacteria and APP of $P$. fucata martensii larvae were much lower than these rates quoted in the literature (Table 2), though these rates were determined using different methods.

The clearance rates on bacteria $\left(0.14\right.$ to $0.26 \mu l$ ind. $^{-1}$ $\mathrm{h}^{-1}$ ) of scuticociliates were similar to those of Pinctada fucata martensii larvae, while those on APP of $P$. fucata martensii larvae were lower than those of ciliates (Table 2). The turnover rates of protists so far reported are 1 to $38 \%$ on a bacterial population in the NW Mediterranean (Rassoulzadegan et al. 1988), 90\% bacteria (Sherr et al. 1987) and 45\% APP off Georgia (Sherr et al. 1991), and $<5 \%$ bacteria and 2 to $20 \%$ APP off New Zealand (James et al. 1996). In Uchiumi Bay, the concentration of $P$. fucata martensii larvae (>100 $\mu \mathrm{m}$ ) was 3.65 ind $.1^{-1}$ during the breeding season, and their average ingestion rates on bacteria and APP were calculated as 347 and 18.3 cells larva ${ }^{-1} \mathrm{~h}^{-1}$, respectively. Thus, the turnover rates on the bacteria and A.P. due to feeding of the P. fucata martensii larvae, were calculated as 0.0003 and $0.0019 \% \mathrm{~d}^{-1}$ (Table 2), suggesting that the grazing impacts of $P$. fucata martensii larvae on picoplankton in Uchiumi Bay is minor relative to that of the ciliates.

The present study demonstrated that Pinctada fucata martensii larvae can ingest 0.8 to $2 \mu \mathrm{m}$ particles, and their grazing impacts on bacteria and APP in Uchiumi Bay may be minor relative to those of ciliates and flagellates. Further studies are necessary in order to evaluate the ecological role of $P$ fucata martensib larvae in coastal environments.

Acknowledgements. We thank Y. Shinomiya and the staff of Uwajima City Fisheries Seeding Production Center, and K. Nakagawa, 3. Shimoda and the staff of Uchiumi Institute of Oceanic and Fishery Science for providing Pinctada fucata 
martensii larvae and food algae. We are also grateful to S. Shiba, N. Ohgaki, Nameko Udaka and members of the marine group in our laboratory. Thanks are also due to Drs Y. Watanabe of Tokyo Metropolitan University and Noriko Takamura of the National Institute of Environmental Sciences for their donation of a minicell-producing mutant of Escherichia coli and a green strain of Synechococcus sp., respectively

\section{LITERATURE CITED}

Baldwin BS (1995) Selective particle ingestion by oyster larvae (Crassostrea virginica) feeding on natural seston and cultured algae. Mar Biol 123:95-107

Baldwin BS, Newell RIE (1991) Omnivorous feeding by planktotrophic larvae of the eastern oyster Crassostrea virginica. Mar Ecol Prog Ser 78:285-301

Baldwin BS, Newell RIE (1995) Relative importance of different size food particles in the natural diet of oyster larvae (Crassostrea virginica). Mar Ecol Prog Ser 120:135-145

Chisholm SW, Olson RJ, Zettler ER, Goericke Ralf, Waterbury JB, Welschmeyer NA (1988) A novel free-living prochlorophyte abundant in the Oceanic euphotic zone. Nature $334: 340-343$

Douillet P (1993a) Bacterivory in Pacific oyster Crassostrea gigas larvae. Mar Ecol Prog Ser 98:123-134

Dowillet $\mathrm{P}$ (1993b) Carbon contribution through bacterivory in larvae of the Pacific oyster Crassostrea virginica. Mar Ecol Prog Ser 102:303-314

Douillet P. Langdon CJ (1993) Effects of marine bacteria on the culture of axenic oyster Crassostrea gigas (Thumberg) larvae. Biol Bull 184:36-51

Fenchel T (1982) Ecology of heterotrophic microflagellates. IV. Quantitative Occurrence and importance as bacterial consumers. Mar Ecol Prog Ser 9:35-42

Ferguson RL, Buckley E, Palumbo AV (1984) Response of marine bacterioplankton to differential filtration and confinement. Appl Environ Microbiol 47:49-55

Fritz LW, Lutz RA, Foote MA, Van Dover CL, Ewart JW (1984) Selective feeding and grazing rates of oyster (Crassostrea virginica) larvae on natural phytoplankton assemblages. Estuaries 7:513-518

Fukushima K (1972) The health of Pinctada fucata martensii and food organisms environment. Shinjugijutsu Kenkyukai Kaiho 10:15-31 (in Japanese)

Gallager SM, Waterbury JB, Stoecker DK (1994) Effecting grazing and utilization of the marine cyanobacterium Synechococcus sp. by larvae of the bivalve Mercenaria mercenaria. Mar Biol 119:251-259

Hayashi M, Seko K (1986) Practical technique for artificial propagation of Japanese pearl oyster (Pinctada fucata). Bull Fish Res Ins 1:39-68 (in Japanese with English abstract)

Hidu H, Tubiash HS (1963) A bacterial basis for the growth of antibiotic-treated bivalve larvae. Proc Natl Shellfish Assoc $54: 25-39$

Hirano R, Ohshima Y (1963) Marine zooplanktonic larval breeding and diets. Bull Jpn Soc Sci Fish 29:282- 297 (in Japanese)

James MR, Hall JA, Barrett DP (1996) Grazing by protozoa in marine coastal and Oceanic ecosystems off New Zealand. NZ J Mar Freshw Res 30:313-324

Kamiyama T (1994) The impact of grazing by microzooplankton in northern Hiroshima Bay, the Seto Inland Sea, Japan. Mar Biol 119:77-88

Kuipers BR, Witte HJ (1999) Grazing impact of microzoo- plankton on different size classes of algae in the North Sea in early spring and mid-summer. Mar Ecol Prog Ser 180: 93-104

Kuwatani M (1965) A study on feeding mechanism of Japanese pearl oyster, Pinctada martensii (Dunker), with special reference to passage of charcoal particles in the digestive system. Bull Jpn Soc Sci Fish 31:789-798 (in Japanese)

Landry MR, Lehner-Fournier JM, Sundstorm JA, Fagerness VL, Selph KE (1991) Discrimination between living and heat-killed prey by a marine zooflagellate, Paraphysomonas vestita (Stokes). J Exp Mar Biol Ecol 146: $139-151$

Lee SH, Kang YC, Fuhrman JA (1995) Imperfect retention of natural bacterioplankotn cells by glass fiber filters. Mar Ecol Prog Ser 119:285-290

McManus GB, Okubo A (1991) On the use of surrogate food particles to measure protistan ingestion. Limnol Oceanogr 36:613-617

Mischke U (1994) Influence of food quality and quantity on ingestion and growth rates of three omnivorous heterotrophic flagellates. Mar Microb Food Webs 8:125-143

Nagata T, Okamoto K (1988) Filtering rates on natural bacteria by Daphnia longispina and Eodiaptomus japonicus in Lake Biwa. J Plankton Res 10:835-850

Nakano S, Ishii N. Manage PM, Kawabata Z (1998a) Trophic roles of heterotrophic nanoflagellates and ciliates among planktonic organisms in a hypereutrophic pond. Aquat Microb Ecol 16:153-161

Nakano S, Koitabashi T, Ueda T (1998b) Seasonal changes in abundance of heterotrophic nanoflagellates and their consumption of bacteria in Lake Biwa with special reference to trophic interactions with Daphnia geleata. Arch Hydrobiol 142:21-34

Olson RJ, Chisholm SW, Zettler ER, Altabet MA, Dusenberry JA (1990) Spatial and temporal distributions of prochlorophyte picoplankton in the North Atlantic Ocean. DeepSea Res 37:1033-1051

Porter KG, Feig YS (1980) The use of DAPI for identifying and counting aquatic microflora. Limnol Oceanogr 25:943-948

Prieur D (1983) Ingestion et digestion de bacteries par les larves de la moule, Mytilus edulis. J Molluscan Stud 12A: $149-153$

Rami M, Porath D (1980) Chlorophyll determination in intact tissues using N, N-dimethylformamide. Plant Physiol 65 $478-479$

Rassoulzadegan F, Laval-Peut M, Sheldon RW (1988) Partitioning of the food ration of marine ciliates between picoand nanoplankton. Hydrobiologia 159:75-88

Riisgard HU, Randlov A, Kristensen PS (1980) Rates of water processing, oxygen consumption and efficiency of particle retention in veligers and young post-metamorphic Mytilus edulis. Ophelia 19:37-47

Rublee PA, Gallegos CL (1989) Use of fluorescently labeled algae (FLA) to estimate microzooplankton grazing. Mar Ecol Prog Ser 51:221-227

Sanders RW, Porter KG, Bennett SJ, DeBiase AE (1989) Seasonal patterns of bacterivory by flagellates, ciliates, rotifers, and cladocerans in a freshwater planktonic community. Limnol Oceanogr 34:673-687

Sawano E (1950) Culture method study of pearl oyster in pond. Fish Mar Stud 3:48-57 (in Japanese)

Seki M (1960) The distribution of Pinctada fucata martensii. Suisan Zoshoku 8:165-179 (in Japanese)

Sherr BF, Sherr EV, Fallon RD (1987) Use of monodispersed, fluorescently labeled bacteria to estimate in situ protozoan bacterivory. Appl Environ Microbiol 53:958-965

Sherr EB, Sherr BF, McDaniel J (1991) Clearance rates of 
$<6 \mu \mathrm{m}$ fluorescently labeled algae (FLA) by estuarine protozoa: potential grazing impact of flagellates and ciliates. Mar Ecol Prog Ser 69:81-92

Stockner JG, Antia NJ (1986) Algal picoplankton from marine and freshwater ecosystems: a multidisciplinary perspective. Can J Fish Aquat Sci 43:2472-2503

Waterbury JB, Watson SW, Valois FW, Franks DG (1986) Bio-

Editorlal responsibility: Otto Kinne (Editor),

Oldendorf/Luhe, Germany logical and ecological characterization of the marine unicellular cyanobacterium Synechococcus. Can Bull Fish Aquat Sci 214:71-120

Weisse $\mathrm{T}$ (1993) Dynamics of autotrophic picoplankton in marine and freshwater ecosystems. In: Jones JG (ed) Advances in microbial ecology 13. Plenum Press, New York, p 327-370

Submitted: March 5, 1999; Accepted: August 25, 1999 Proofs received from author(s): January 18, 2000 